\title{
In situ redox speciation analysis of chromium in water by diffusive gradients in thin films using a DE81 anion exchange membrane
}

\author{
Carlos A. Suárez a , Thays V. de Simone ${ }^{a}$, Amauri A. Menegário a,b,*, Ana M.C.M. Rolisola a , \\ Karen S. Luko ${ }^{a}$, Didier Gastmans ${ }^{a}$, Fabiano T. da Conceição ${ }^{b}$, Chang H. Kiang ${ }^{a, b}$ \\ ${ }^{a}$ Centro de Estudos Ambientais, UNESP - Univ Estadual Paulista, Av. 24-A, 1515, CEP 13506-900 Rio Claro, SP, Brazil \\ ${ }^{\mathrm{b}}$ Instituto de Geociências e Ciências Exatas, UNESP - Univ Estadual Paulista, Av. 24-A, 1515, CEP 13506-900 Rio Claro, SP, Brazil
}

\section{A R T I C L E I N F O}

\section{Article history:}

Received 14 December 2015

Received in revised form

23 March 2016

Accepted 25 March 2016

Available online 26 March 2016

\section{Keywords:}

Diffusive gradients

Thin films

Passive sampler

Paper-based DGT

DE81 membrane

Chromium speciation

\begin{abstract}
A B S T R A C T
A method for the in situ redox speciation analysis of chromium in water by the diffusive gradients in thin films (DGT) technique using a DE81 anion exchange membrane was successfully developed. For the selective uptake of $\mathrm{Cr}(\mathrm{VI})$, a DGT device containing an anion exchange membrane DE81 (cellulose acetate chromatographic paper) was used (DE81-DGT), while selective uptake of $\mathrm{Cr}$ (III) was carried out using DGT devices containing the Chelex-100 resin (Chelex-100-DGT). A correlation coefficient of 0.993 was obtained for the linearity of the immersion curves (mass versus time) using DE81-DGT. The diffusion coefficient values for $\mathrm{Cr}(\mathrm{VI})$ through the agarose diffusive layer were equal to $4.89 \pm 0.5 \times 10^{-6} \mathrm{~cm}^{2} \mathrm{~s}^{-1}$ and $3.95 \pm 0.02 \times 10^{-6} \mathrm{~cm}^{2} \mathrm{~s}^{-1}\left(\mathrm{~T}=23 \pm 1{ }^{\circ} \mathrm{C}, \mathrm{I}=0.03 \mathrm{~mol} \mathrm{~L}^{-1} \mathrm{NaNO}_{3}\right)$ were obtained by using diffusion cell and immersion curves, respectively. The retention of $\mathrm{Cr}(\mathrm{VI})$ by the DE81 membrane in a synthetic sample and river water was not affected by the $\mathrm{pH}$ over a wide range 4-9). Recoveries of $\mathrm{Cr}(\mathrm{VI}) \mathrm{between}$ $90 \%$ and $120 \%$ from solutions of ionic strength ranging from 0.01 to $0.5 \mathrm{~mol} \mathrm{~L}^{-1} \mathrm{NaNO}_{3}$ were achieved. Finally, the redox speciation analysis of $\mathrm{Cr}(\mathrm{III})$ and $\mathrm{Cr}(\mathrm{VI})$ in spiked river water and synthetic samples was performed with recoveries greater than $80 \%$ and $87 \%$ by using Chelex-100-DGT and DE81-DGT devices, respectively. Those results were in excellent agreement with the diphenylcarbazide spectrophotometric method.
\end{abstract}

(c) 2016 Elsevier B.V. All rights reserved.

\section{Introduction}

Chromium is widely distributed in the environment due to its various industrial applications such as electroplating, chromiumbased pigments, mining, leather tanning and chromium alloy production $[1,2]$. It commonly exists in two oxidation states in natural water systems: trivalent chromium $\mathrm{Cr}(\mathrm{III})$ and hexavalent chromium $\mathrm{Cr}(\mathrm{VI})$ [1]. While $\mathrm{Cr}(\mathrm{III})$ is considered an essential human nutrient (with some exceptions in recent studies) [3], $\mathrm{Cr}(\mathrm{VI})$ is well known as being harmful to human health[1]. Chromium speciation has been extensively studied, mainly in drinking water. One of the main reasons for this is the low maximum concentration level of total chromium in drinking water $\left(50 \mu \mathrm{g} \mathrm{L}^{-1}\right)$ recommended by the World Health Organization, in addition to its known health effects [4]. The maximum permissible concentrations of these chromium species in wastewater have been established at $1 \mathrm{mg} \mathrm{L}^{-1}$ for $\mathrm{Cr}$ (III) and $0.1 \mathrm{mg} \mathrm{L}^{-1}$ for $\mathrm{Cr}(\mathrm{VI})$ [5]. Thus, it

\footnotetext{
* Corresponding author at: Centro de Estudos Ambientais, UNESP - Univ Estadual Paulista, Av. 24-A, 1515, CEP 13506-900 Rio Claro, SP, Brazil.

E-mail address: amenega@rc.unesp.br (A.A. Menegário).
}

becomes extremely necessary to develop reliable methods for these determination of chromium species in water [2].

Developed in the early 1990s [6,7], the diffusive gradients in thin film (DGT) technique appears to be a powerful tool for speciation analysis. This technique offers the possibility of selective in situ sampling of the species [7,8], avoiding the necessity of sample storage. By using a simple relation (Eq. (1)), this technique allows the calculation of the time-integrated concentration of analytes during the sampling time. A DGT device consists of a diffusive gel disc (commonly a polyacrylamide-agarose gel) used as a diffusion layer of known thickness $(\Delta \mathrm{g})$ and diffusion area (A) over a binding layer (Chelex-100 impregnated in a polyacrylamide gel). Therefore, after determining the accumulated mass (M) of the analyte in the binding layer, it is possible to calculate the average concentration of the analyte in the field sample studied because we already know the analyte diffusion coefficient through the gel (D) and the exposure time $(t)$.

$\mathrm{C}=\mathrm{M} \Delta \mathrm{g}(\mathrm{D} \text { t A })^{-1}$

To date, only a few approaches for the determination of the $\mathrm{Cr}$ redox species by DGT rigorously matched the IUPAC [9] definition of speciation analysis. The Chelex-100 binding layer for $\mathrm{Cr}(\mathrm{III})$ with 
no retention of $\mathrm{Cr}(\mathrm{VI})$ [10] is based on combining a DGT for the selective retention of $\mathrm{Cr}(\mathrm{III})$ and the diffusive equilibrium in thin films (DET) for the selective uptake of $\mathrm{Cr}(\mathrm{VI})$ on a diffusive layer. Additionally, a polyquaternary ammonium salt liquid binding layer and a dialysis membrane as the diffusive layer has been proposed for $\mathrm{Cr}(\mathrm{VI})$ [11]. In both approaches, only one species was retained in the binding phase and can thus be pre-concentrated. N-methylD-glucamine (NMDG) has been recently proposed as a DGT ligand (NMDG-DGT) to sample $\mathrm{Cr}(\mathrm{VI})$ in situ. This method was evaluated for natural fresh water and was able to pre-concentrate $\mathrm{Cr}(\mathrm{VI})$ even in the presence of a ten-fold greater $\mathrm{Cr}$ (III) concentration. However, this method is limited by ionic strength (I) which ranges from 0.0001 to $0.075 \mathrm{~mol} \mathrm{~L}^{-1}$ [12].

The binding phase sodium poly(aspartic acid) (PASP) and poly (quaternary ammonium) salt (PQAS) were used for the speciation of $\mathrm{Cr}(\mathrm{III})$ and $\mathrm{Cr}(\mathrm{VI})$ using DGT. The concentration of $\mathrm{Cr}(\mathrm{VI})$ was determined by a DGT device with the PQAS salt solution and $\mathrm{Cr}$ (III) was determined by a DGT device with the PASP solution. The proposed approach was evaluated for the analysis of tap water. Recoveries of the spiked $\mathrm{Cr}(\mathrm{VI})$ and $\mathrm{Cr}(\mathrm{III})$ were $98.2-107.7 \%$ and 97.9-105.3\%, respectively[13].

In this work, the chemical speciation of $\mathrm{Cr}(\mathrm{VI})$ and $\mathrm{Cr}(\mathrm{III})$ in river water was performed for the first time with the DGT technique using a diethylaminoethyl acetate anion exchange membrane (DE81) for the selective retention of $\mathrm{Cr}(\mathrm{VI})$ in combination with an earlier-reported [10] approach to retain $\mathrm{Cr}(\mathrm{III})$ in the Chelex-100 binding layer.

\section{Materials and methods}

\subsection{Reagents}

All reagents used were from an analytical grade. Solutions were prepared with ultrapure water with a resistivity of $18 \mathrm{M} \Omega \mathrm{cm}^{-1}$ (Milli-Q Millipore Academic, USA). The DGT devices and Chelex100 binding gels were purchased from DGT Research Ltd. (Lancaster, UK). The cellulose acetate membrane filters (25-mm diameter, $0.45-\mu \mathrm{m}$ pore size and $0.13-\mathrm{mm}$ thickness) were purchased from GVS Filter Technology. The Whatman ${ }^{\text {B }}$ DE81 cellulose paper with a weak basic anion exchanger, diethylaminoethyl functional groups $\left(1.7 \mu \mathrm{eq} \mathrm{cm}^{-2}, 0.20 \mathrm{~mm}\right.$ ) was obtained from GE Healthcare Life Science. Diffusive gels were prepared with Agarose RATM, biotechnology grade (AMRESCO, USA).

\subsection{Methods}

The determination of total chromium was carried out by inductively coupled plasma optical emission spectrometry (ICP-OES) using an іСАРтм 6000 Series (Thermo Scientific ${ }^{\mathrm{TM}}$, Germany). The ICP-OES operating conditions are listed in Table 1. Additionally, a DR $2800^{\mathrm{TM}}$ Portable Spectrophotometer (Hach Company, USA) was employed to measure $\mathrm{Cr}(\mathrm{VI})$ by the diphenylcarbazide method[14].

All DGT devices, diffusion cells and other plastic components

Table 1

ICP-OES operating conditions.

\begin{tabular}{lll}
\hline Operating parameters & Units & Axial \\
\hline RF power & $(\mathrm{W})$ & 1,150 \\
Gas flow rate & $\left(\mathrm{L} \mathrm{min}^{-1}\right)$ & 0.7 \\
Auxiliary gas flow rate & $\left(\mathrm{L} \mathrm{min}^{-1}\right)$ & 0.5 \\
Sample flow rate & $\left(\mathrm{mL} \mathrm{min}^{-1}\right)$ & 2 \\
Nebulization chamber & & Cyclonic \\
Nebulizer & & V-Groove \\
Emission line & $(\mathrm{nm})$ & 267.72 \\
\hline
\end{tabular}

used in this work were cleaned by immersing in a $20 \%(\mathrm{v} / \mathrm{v}) \mathrm{HNO}_{3}$ solution for a period of $4 \mathrm{~h}$ and then rinsing with ultrapure water. The DE81 membrane and cellulose acetate membrane were decontaminated with nitric acid solution $(10 \%, v / v)$ for $24 \mathrm{~h}$. After that, the membranes were washed with ultrapure water in order to removing acid residues until $\mathrm{pH}$ of the wash water reached values of about pH 5-6. Agarose diffusive gels were prepared similarly as previously described [15]. The cellulose acetate membranes and the agarose diffusive gels were stored in a $0.03 \mathrm{~mol} \mathrm{~L}^{-1}$ sodium nitrate solution and the DE81 membrane was stored in ultrapure water at $4{ }^{\circ} \mathrm{C}$.

\subsubsection{Elution factor of $\mathrm{Cr}(\mathrm{VI})$ from the DE81 membrane}

To determine the uptake and elution efficiency of $\mathrm{Cr}(\mathrm{VI})$ from the DE81 membrane, three DE81 membrane discs were placed in a vessel containing $250 \mathrm{~mL}$ of $30 \mu \mathrm{g} \mathrm{L}^{-1} \mathrm{Cr}(\mathrm{VI})$ solution with an ionic strength of $0.03 \mathrm{~mol} \mathrm{~L}^{-1} \mathrm{NaNO}_{3}$ and $\mathrm{pH}=6.1$. The DE81 membrane discs were removed after $12 \mathrm{~h}$ and eluted with $3 \mathrm{~mL}$ of $10 \%(v / v)$ nitric acid with stirring for $24 \mathrm{~h}$. The elution factor $\left(f_{e}\right)$ was calculated according to Eq. (2),

$\mathrm{f}_{\mathrm{e}}=\mathrm{M}_{\mathrm{e}} \mathrm{M}_{\mathrm{r}}{ }^{-1}$

where $\mathrm{M}_{\mathrm{e}}$ is the eluted mass of $\mathrm{Cr}(\mathrm{VI})$ from the DE81 membranes and $\mathrm{M}_{\mathrm{r}}$ is the retained mass. The retained mass was calculated from the difference between the concentration of the solution before and after the immersion of DE81 membranes.

\subsubsection{Diffusion coefficient measurements}

The diffusion coefficient of $\mathrm{Cr}(\mathrm{VI})$ was determined by both the diffusion cell and deployment curve methods. The diffusion cell method, as previously reported [16,17], was carried out by preparation of two solutions, $\mathrm{A}$ and $\mathrm{B}$, with equal ionic strength ( $0.03 \mathrm{~mol} \mathrm{~L}^{-1} \mathrm{NaNO}_{3}$ and $\mathrm{pH}=5.6$ ). Solution A was prepared with no addition of $\mathrm{Cr}(\mathrm{VI})$ while solution $\mathrm{B}$ was prepared to contain $5 \mathrm{mg} \mathrm{L}^{-1}$ of $\mathrm{Cr}(\mathrm{VI})$. During a period of $2 \mathrm{~h}, 1 \mathrm{~mL}$ was collected from solution A every 15 minutes and acidified with nitric acid solution (2\%, v/v). For the deployment curve method, $4 \mathrm{~L}$ of $60 \mu \mathrm{g} \mathrm{L}^{-1} \mathrm{Cr}(\mathrm{VI})$ solution $\left(\mathrm{I}=0.03 \mathrm{~mol} \mathrm{~L}^{-1} \mathrm{NaNO}_{3}, \mathrm{pH}=5.6\right.$ at $\left.23 \pm 1{ }^{\circ} \mathrm{C}\right)$ were prepared. The DGT devices were assembled and placed into the solution. These DGT devices were retrieved in duplicate after 2, 4, 6, $8 \mathrm{~h}$ and the $\mathrm{Cr}(\mathrm{VI})$ was eluted from the discs as described above. The diffusion coefficient (D, $\left.\mathrm{cm}^{2} \mathrm{~s}^{-1}\right)$ was obtained by Eq. (3),

$\mathrm{D}=\mathrm{a} \Delta \mathrm{g}\left(\mathrm{AC}_{\mathrm{S}}\right)^{-1}$

where $\mathbf{a}$ is the slope obtained by plotting the mass (ng) of $\mathrm{Cr}(\mathrm{VI})$ versus time ( $\left.\mathrm{ng} \mathrm{s}^{-1}\right) ; \Delta \mathbf{g}$ is the gel thickness $(0.013 \mathrm{~cm}$ cellulose acetate membrane plus $0.08 \mathrm{~cm}$ agarose diffusive gel thicknesses); $\mathbf{A}\left(\mathrm{cm}^{2}\right)$ is the exposed area of the gel in the DGT devices $\left(3.14 \mathrm{~cm}^{2}\right)$ or in the diffusion cell $\left(1.77 \mathrm{~cm}^{2}\right) ; \mathbf{C}_{\mathbf{s}}$ is the $\mathrm{Cr}(\mathrm{VI})$ concentration of the deployment solution or concentration of solution $\mathrm{B}$.

\subsection{3. $\mathrm{pH}$ and ionic strength}

To evaluate the influence of $\mathrm{pH}$ on $\mathrm{Cr}(\mathrm{VI})$ uptake by the DE81 membrane, five solutions (1 L) containing $100 \mu \mathrm{g} \mathrm{L}^{-1} \mathrm{Cr}(\mathrm{VI})$ $\left(\mathrm{I}=0.03 \mathrm{~mol} \mathrm{~L}^{-1} \mathrm{NaNO}_{3}\right)$ were prepared and the $\mathrm{pH}$ was adjusted to $4.0,5.0,6.0,7.0$ or 9.0 . Similarly, to evaluate the ionic strength

Table 2

Physical and chemical parameters of the synthetic samples (Mean $\pm S D, n=3$ ).

\begin{tabular}{llll}
\hline Solutions & Cr species & Conductivity $\left(\mathrm{mS} \mathrm{cm}^{-1}\right)$ & $\mathrm{pH}$ \\
\hline 1 & $\mathrm{Cr}(\mathrm{III})$ & $2.63 \pm 0.01$ & $5.4 \pm 0.2$ \\
2 & $\mathrm{Cr}(\mathrm{VI})$ & $2.64 \pm 0.04$ & $5.4 \pm 0.2$ \\
3 & $\mathrm{Cr}(\mathrm{III})+\mathrm{Cr}$ & $2.64 \pm 0.03$ & $5.4 \pm 0.2$ \\
& $(\mathrm{VI})$ & & \\
\hline
\end{tabular}


Table 3

Physical and chemical parameters measured in the Piracicaba river sample (Mean $\pm S D, n=3$ )

\begin{tabular}{lll}
\hline $\begin{array}{l}\text { Conductivity } \\
{ }^{\mathrm{a}} \mathrm{I}\end{array}$ & $\left(\mu \mathrm{S} \mathrm{cm}^{-1}\right)$ & $515 \pm 2$ \\
& $\left(\mathrm{~mol} \mathrm{~L}^{-1}\right) \times$ & $6.50 \pm 0.03$ \\
${ }^{\mathrm{b}} \mathrm{TDS}$ & $10^{-3}$ & \\
${ }^{\mathrm{c}} \mathrm{TOC}$ & $\left(\mathrm{mg} \mathrm{L}^{-1}\right)$ & $330 \pm 1$ \\
$\mathrm{~T}$ & $\left(\mathrm{mg} \mathrm{L}^{-1}\right)$ & $7.13 \pm 0.16$ \\
$\mathrm{Eh}$ & $\left({ }^{\circ} \mathrm{C}\right)$ & $23.5 \pm 0.7$ \\
$\mathrm{pH}$ & $(\mathrm{V})$ & $0.195 \pm 0.001$ \\
$\mathrm{HCO}_{3}{ }^{-}$ & & $7.9 \pm 0.04$ \\
$\mathrm{~F}^{-}$ & $\left(\mathrm{mg} \mathrm{L}^{-1}\right)$ & 85 \\
$\mathrm{Cl}^{-}$ & $\left(\mathrm{mg} \mathrm{L}^{-1}\right)$ & 0.29 \\
$\mathrm{NO}_{2}{ }^{-}$ & $\left(\mathrm{mg} \mathrm{L}^{-1}\right)$ & 47 \\
$\mathrm{NO}_{3}{ }^{-}$ & $\left(\mathrm{mg} \mathrm{L}^{-1}\right)$ & 0.40 \\
$\mathrm{PO}_{4}{ }^{3-}$ & $\left(\mathrm{mg} \mathrm{L}^{-1}\right)$ & 30 \\
$\mathrm{SO}_{4}{ }^{2-}$ & $\left(\mathrm{mg} \mathrm{L}^{-1}\right)$ & 0.94 \\
\hline
\end{tabular}

${ }^{a} \mathrm{I}=$ ionic strength, values calculated according Griffin and Jurinak (1973) [18].

${ }^{\mathrm{b}} \mathrm{TDS}=$ total dissolved solids.

c $\mathrm{TOC}=$ total organic carbon.

effect, four flasks containing $1 \mathrm{~L}$ of $100 \mu \mathrm{g} \mathrm{L}^{-1} \mathrm{Cr}(\mathrm{VI})$ solutions were prepared $(\mathrm{pH}=5.6)$. For the individual flasks, ionic strengths were $0.005,0.01,0.03$ and $0.5 \mathrm{~mol} \mathrm{~L}^{-1} \mathrm{NaNO}_{3}$. Both experiments were carried out in duplicate at $23 \pm 1^{\circ} \mathrm{C}$. The DGT devices were deployed and retrieved after a deployment period of $6 \mathrm{~h}$.

\subsubsection{Redox speciation of chromium using DGT technique}

Synthetic samples and a river water sample containing $\mathrm{Cr}$ (III) and/or $\mathrm{Cr}(\mathrm{VI})$ were used to evaluate the efficiency of the proposed approach for redox speciation analysis of chromium. Tables 2 and 3 show the physical and chemical parameters of the synthetic sample and the Piracicaba river sample, respectively, measured during speciation analysis. The ionic strength was calculated according to previous work [18]. Two DGT devices containing DE81 membrane discs and two containing Chelex-100 resin discs were immersed in solutions and in the Piracicaba river sample for $6 \mathrm{~h}$.

The diffusion gel used for the DGT devices containing DE81 membrane discs was agarose gel 1.5\% (w/v) and for DGT devices containing Chelex-100 discs was polyacrylamide gel cross-linked with an agarose derivative purchased from DGT Research Ltd., UK.

The Chelex-100 resin gel (also purchased from DGT Research Ltd.) was washed with ultrapure water to remove excess solution.

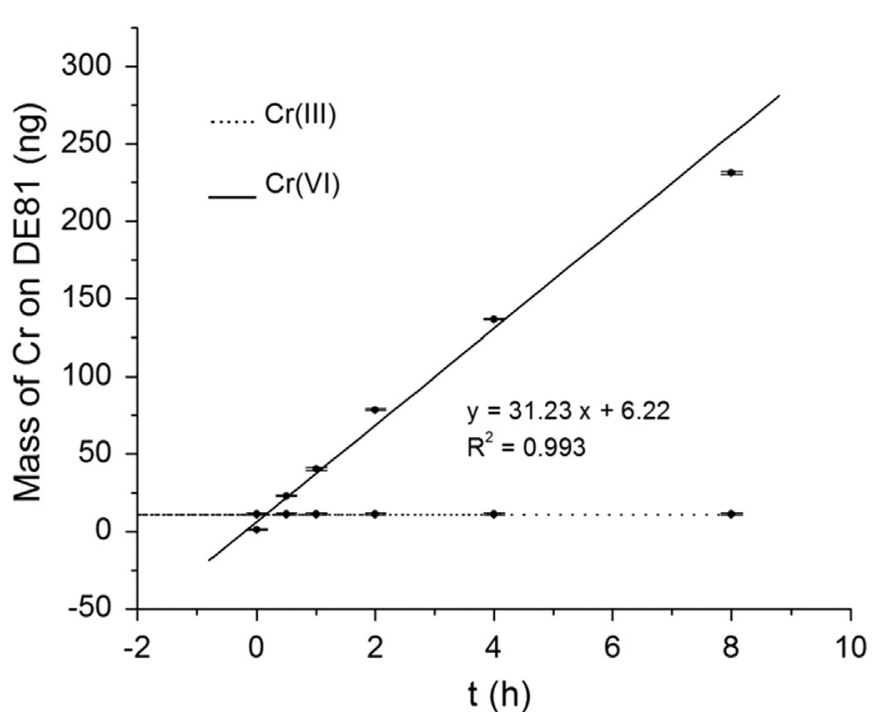

Fig. 1. Deployment curve obtained by using the DE81 membrane. Deployment solution $60 \mu \mathrm{g} \mathrm{L}^{-1} \mathrm{Cr}(\mathrm{VI}) \quad\left(\mathrm{I}=0.03 \mathrm{~mol} \mathrm{~L}^{-1} \mathrm{NaNO}_{3}, \mathrm{pH}=5.6,23 \pm 1{ }^{\circ} \mathrm{C}\right) ; \mathrm{n}=2$; Mean \pm SD.
The elution of $\mathrm{Cr}(\mathrm{III})$ from Chelex-100 discs was performed with $1 \mathrm{~mL}$ of $\mathrm{HNO}_{3}\left(1 \mathrm{~mol} \mathrm{~L}^{-1}\right)$. The discs were shaken using an orbital shaker (Labnet Instruments, Inc., USA) for a period of $24 \mathrm{~h}$.

The elution factor used for elution of $\mathrm{Cr}$ (III) from the Chelex100 resin was $0.79 \pm 0.06$ [10], and diffusion coefficient was $4.50 \times 10^{-6} \mathrm{~cm}^{2} \mathrm{~s}^{-1}[16]$.

\section{Results and discussions}

\subsection{Elution factor and $\operatorname{Cr}(\mathrm{VI})$ diffusion coefficient}

An elution factor of $0.89 \pm 0.01$ was obtained using Eq. (2). This value is better than those reported for other binding phases, such as the elution efficiency of $0.79 \pm 0.07$ for $\mathrm{Cr}$ (III) on Chelex-100[10] and is similar to the elution factor (0.88) obtained for $U$ when using a DE81 membrane [19].

The diffusion coefficient for $\mathrm{Cr}(\mathrm{VI})$ in the agarose gel $\left(\mathrm{I}=0.03 \mathrm{~mol} \mathrm{~L}^{-1} \quad \mathrm{NaNO}_{3}\right.$ and $\mathrm{pH}=5.6$ at $\left.23 \pm 1^{\circ} \mathrm{C}\right)$ was $4.89 \pm 0.5 \times 10^{-6} \mathrm{~cm}^{2} \mathrm{~s}^{-1}$ obtained by the diffusion cell method (from a linear relationship with a slope of $0.893 \mathrm{ng} \mathrm{s}^{-1}$ and $\mathrm{R}^{2}$ between 0.96 and 0.97 ).

The accumulated mass of $\mathrm{Cr}(\mathrm{VI})$ in the DGT devices containing DE81 membrane versus time showed a linear behaviour (characterized by an $\mathrm{R}^{2}=0.993$ ) during the immersion time (Fig. 1 ), demonstrating the capacity of the proposed material to be used as the binding layer for the DGT technique for sampling $\mathrm{Cr}(\mathrm{VI})$. From these data and Eq. (3), a diffusion coefficient of $3.95 \pm 0.02 \times 10^{-6} \mathrm{~cm}^{2} \mathrm{~s}^{-1}$ was obtained in agarose gel $\left(\mathrm{I}=0.03 \mathrm{~mol} \mathrm{~L}^{-1} \mathrm{NaNO}_{3}, \mathrm{pH}=5.6\right.$ at $\left.23 \pm 1{ }^{\circ} \mathrm{C}\right)$. This value is similar to that obtained by the diffusion cell.

By comparison, Chen et al. [11] have reported a value of $\mathrm{D}=2.91 \pm 0.12 \times 10^{-7} \mathrm{~cm}^{2} \mathrm{~s}^{-1}$ for $\mathrm{Cr}(\mathrm{VI})$ in a dialysis membrane, $16 \%$ lower than the value obtained in the present method. On the other hand, Pan et al. [12] reported a 51\% higher diffusion coefficient value for a polyacrylamide hydrogel.

The value of $3.95 \pm 0.02 \times 10^{-6} \mathrm{~cm}^{2} \mathrm{~s}^{-1}$ was assumed as the diffusion coefficient for further experiments. In a solid-phase extraction test (batch mode), the average of the masses of $\mathrm{Cr}(\mathrm{VI})$ retained by a DE81 disc was $653.50 \pm 12.26 \mathrm{ng}$ ( $12 \mathrm{~h}$ of immersion). Because the mass of one DE81 disc is $0.0403 \pm 0.0004 \mathrm{~g}$, the exchange capacity (EC) value obtained for the binding material

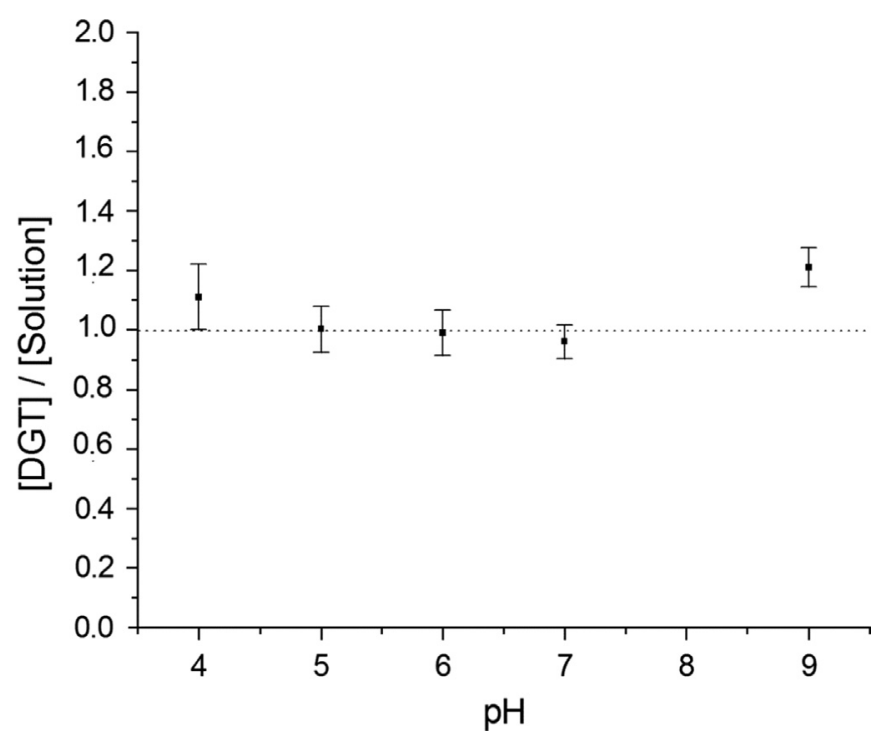

Fig. 2. Influence of $\mathrm{pH}$ on the $\mathrm{Cr}(\mathrm{VI})$ uptake by the $\mathrm{DE} 81$ membrane. Deployment solution containing $100 \mu \mathrm{g} \mathrm{L}^{-1}$ of $\mathrm{Cr}(\mathrm{VI}) ; \mathrm{I}=0.03 \mathrm{~mol} \mathrm{~L}^{-1} \mathrm{NaNO}_{3}$ at $24 \pm 0.5^{\circ} \mathrm{C}$; deployment time $=6 \mathrm{~h} ; \mathrm{n}=3$; Mean $\pm \mathrm{SD}$. 


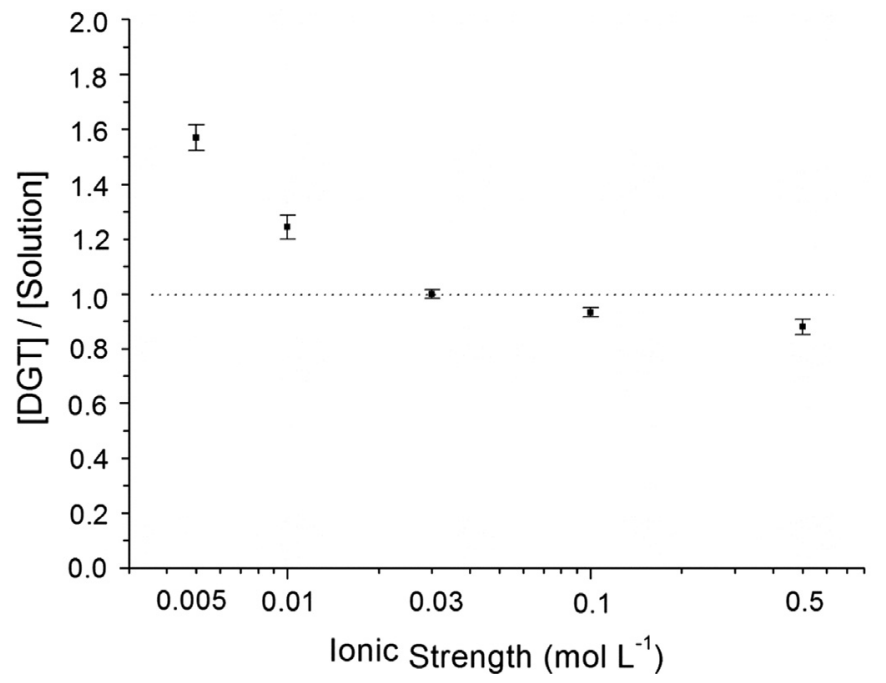

Fig. 3. Influence of $\mathrm{I}$ on the $\mathrm{Cr}(\mathrm{VI})$ uptake by the DE81 membrane. Deployment solution containing $100 \mu \mathrm{g} \mathrm{L}^{-1} \mathrm{Cr}(\mathrm{VI}) ; 23 \pm 1{ }^{\circ} \mathrm{C}$; deployment time $=6 \mathrm{~h} ; \mathrm{n}=3$. Mean \pm SD.

was $16.22 \pm 0.30 \mu \mathrm{g} \mathrm{g}^{-1}(\mathrm{n}=3)$. Based on these comments, it can be seen from Fig. 1 that the total capacity of retained $\mathrm{Cr}(\mathrm{VI})$ was not attained in a time period of $8 \mathrm{~h}$.

Considering the slope of the immersion curve, a mass of $31.23 \mathrm{ng}$ of $\mathrm{Cr}(\mathrm{VI})$ is retained per hour from a solution containing $59( \pm 1.5) \mu \mathrm{g} \mathrm{L}^{-1} \mathrm{Cr}(\mathrm{VI})$. Assuming a $\mathrm{Cr}(\mathrm{VI})$ concentration of $1 \mathrm{ng} \mathrm{mL}^{-1}$ in the aquatic system a deployment of $96 \mathrm{~h}$ (four days) will take $59.9 \mathrm{ng}$ of $\mathrm{Cr}$. This value represents only $9 \%$ of the exchange capacity of the binding layer.

\subsection{Effect of $\mathrm{pH}$ and ionic strength on $\mathrm{Cr}(\mathrm{VI})$ uptake}

The uptake of $\mathrm{Cr}(\mathrm{VI})$ by the DE81 was independent of the solution $\mathrm{pH}$ over the entire studied $\mathrm{pH}$ range (4-9) (Fig. 2) because the $\mathrm{HCrO}_{4}{ }^{-}$and $\mathrm{CrO}_{4}{ }^{2-}$ anionic species of $\mathrm{Cr}(\mathrm{VI})$ occur in this $\mathrm{pH}$ range. This result is in agreement with that reported in a previous study $[11,12]$.

The results obtained showed that the $\mathrm{Cr}(\mathrm{VI})$ uptake by DE81 was almost unaffected by ionic strength in the range of $0.01-0.5 \mathrm{~mol} \mathrm{~L}^{-1}$ with recoveries between $88 \%$ and $120 \%$ (Fig. 3). However, for an ionic strength value of $0.005 \mathrm{~mol} \mathrm{~L}^{-1} \mathrm{NaNO}_{3}$, the diffusion of $\mathrm{Cr}(\mathrm{VI})$ experienced an increase. This resulted in an overestimated concentration measured by DGT approximately $60 \%$ higher than the actual value. Similar results were earlier reported for other ions and diffusive layers [20]. Pan et al. [12] reported a range of ionic strength from 0.0001 to $0.075 \mathrm{~mol} \mathrm{~L}^{-1}$ for $\mathrm{Cr}(\mathrm{VI})$ that could be useful for lower ionic strength water systems. On other hand, the proposed approach could be applied to water systems with higher ionic strength.
For higher ionic strength values $\left(0.5 \mathrm{~mol} \mathrm{~L}^{-1}\right)$, a small decrease was observed in the $\mathrm{Cr}(\mathrm{VI})$ mass retained on DE81 of up to $20 \%$ (Fig. 3). This behaviour may happen because of the competition of the $\mathrm{NO}_{3}{ }^{-}$and $\mathrm{Cr}(\mathrm{VI})$ ions by the DE81 binding sites, as reported for DE81 on the uptake of $U$ anions [19] (for a polyacrylamide hydrogel).

\subsection{Selective measurement of $\mathrm{Cr}(\mathrm{VI})$ and speciation analysis of $\mathrm{Cr}$ (VI) and $\mathrm{Cr}(\mathrm{III})$}

Satisfactory recoveries (greater than $87 \%$ of $\mathrm{Cr}(\mathrm{VI})$ ) and a low uptake of $\mathrm{Cr}$ (III) (less than 17\%) from the synthetic sample were obtained for the DE81 binding layer (Table 4), indicating the potential for its use in the selective measuring for $\mathrm{Cr}(\mathrm{VI})$ by DGT. Additionally, at this point, it is important to keep in mind that the DE81 membrane has approximately $85 \%$ of water $\left(0.22 \mathrm{~mL}\right.$ of $\left.\mathrm{H}_{2} \mathrm{O}\right)$ when hydrated. Therefore, part of the $17 \%$ of the $\operatorname{Cr}(\mathrm{III})$ inside the membrane came from the mass of $\mathrm{Cr}$ (III) in equilibrium with the bulk solution and was not linked to the functional group of the DE81 membrane. As the amount of $\mathrm{Cr}$ (III) in the binding membrane coming from equilibrium with the bulk solution is constant, this amount can be considered as insignificant when a longer deployment time is used. This fact can be clearly observed in Fig. 1. Assuming that the DE81 contains $0.22 \mathrm{~mL}$ of $\mathrm{H}_{2} \mathrm{O}$ and is exposed to a $50 \mathrm{ng} \mathrm{mL} \mathrm{m}^{-1}$ solution of $\mathrm{Cr}(\mathrm{III})$, the mass of $\mathrm{Cr}(\mathrm{III})$ present in one DE81 disc due to diffusional equilibrium is equal to $11.01 \pm 0.53 \mathrm{ng}$, which corresponds to less than $5 \%$ the mass of $\mathrm{Cr}$ (VI) retained on the DE81 after $8 \mathrm{~h}$ of deployment (Fig. 1) from a solution containing approximately 50 to $60 \mathrm{ng} \mathrm{mL} \mathrm{L}^{-1} \mathrm{Cr}(\mathrm{VI})$. On other hand, this value can be increased to approximately $40 \%$ when $1 \mathrm{~h}$ of deployment is used. As a comparison, Pan et al. [12] reported a $5 \%$ residual mass of $\mathrm{Cr}$ (III) out of the total retained mass of $\mathrm{Cr}(\mathrm{VI})$ after $72 \mathrm{~h}$ of deployment.

Furthermore, as previously reported [10], the Chelex-100 resin has been demonstrated as inadequate for the uptake $\mathrm{Cr}(\mathrm{VI})$, showing recoveries of approximately $20 \%$, in contrast to recoveries of $80 \%$ for $\mathrm{Cr}(\mathrm{III})$, as shown in Table 4 . These results were consistent with the direct measurement of total $\mathrm{Cr}$ determined by ICP-OES.

The proposed method was also effective for chromium speciation in synthetic sample as well in spiked river water. Results obtained by combining the spectrophotometric method (for selective determination of $\mathrm{Cr}(\mathrm{VI})$ ) with ICP-OES were in good agreement with the proposed method for the redox speciation analysis of chromium for both synthetic samples and spiked river waters (Table 4).

Compared to the previous method based on combining DGT for the determination of $\mathrm{Cr}$ (III) with DET for the determination of the $\mathrm{Cr}(\mathrm{VI})$ concentration [10], the proposed approach allows for improvement in the LOD for the determination of $\mathrm{Cr}(\mathrm{VI})$ because this species can also be pre-concentrated. For example, when determining $\mathrm{Cr}(\mathrm{VI})$ by using DET and ICP-OES (axial view) a LOD of

Table 4

Concentrations of $\mathrm{Cr}(\mathrm{VI})$ and $\mathrm{Cr}(\mathrm{III})$ measured in synthetic and river samples by the proposed approach. (Mean $\pm \mathrm{SD}, \mu \mathrm{g} \mathrm{L}^{-1}, \mathrm{n}=3$ ).

\begin{tabular}{|c|c|c|c|c|c|c|c|}
\hline \multirow[t]{2}{*}{ Sample } & & \multicolumn{3}{|l|}{ DGT } & \multirow{2}{*}{$\frac{\text { ICP-OES }}{\text { [Total] }}$} & \multicolumn{2}{|c|}{ Colorimetry } \\
\hline & & [Chelex] & [DE81] & [Total] $^{\mathrm{a}}$ & & {$[\mathrm{Cr}(\mathrm{VI})]$} & {$[\mathrm{Cr}(\mathrm{III})]^{\mathrm{b}}$} \\
\hline 1 & $\mathrm{Cr}(\mathrm{III})$ & $37 \pm 2$ & $9 \pm 1$ & $46 \pm 2$ & $42 \pm 1$ & $6 \pm 1$ & $35 \pm 1$ \\
\hline 2 & $\mathrm{Cr}(\mathrm{VI})$ & $9 \pm 1$ & $47 \pm 2$ & $56 \pm 2$ & $54 \pm 1$ & $54 \pm 1$ & $<\mathrm{LD}^{\mathrm{c}}$ \\
\hline 3 & $\mathrm{Cr}(\mathrm{III} / \mathrm{VI})$ & $40 \pm 1$ & $53 \pm 2$ & $93 \pm 2$ & $97 \pm 1$ & $54 \pm 1$ & $43 \pm 1$ \\
\hline 4 & Piracicaba River ${ }^{d}$ & $31 \pm 1$ & $59 \pm 1$ & $89 \pm 1$ & $85 \pm 1$ & $53 \pm 1$ & $32 \pm 1$ \\
\hline
\end{tabular}

${ }^{\text {a }}$ Obtained by sum of [Chelex]+[DE81].

${ }^{\mathrm{b}}$ Obtained by subtracting [Total] (obtained by ICP-OES) and [Cr(VI)] (obtained by spectrophotometry).

${ }^{c} \mathrm{LD}_{\mathrm{ICP}-\mathrm{OES}}=0.6 \mu \mathrm{g} \mathrm{L}{ }^{-1}$.

${ }^{\mathrm{d}}$ Spiked with $\mathrm{Cr}(\mathrm{III})$ and $\mathrm{Cr}(\mathrm{VI})$. 
$0.6 \mathrm{ng} \mathrm{mL^{-1 }}$ can be estimated. This LOD can be improved to approximately $0.04 \mathrm{ng} \mathrm{mL}^{-1}$ (for a deployment time of four days) when using the proposed approach associated with ICP-OES. The LOD was estimated considering the instrumental LOD of ICP and the pre-concentration factor ( 15 for a deployment time of four days) obtained by the proposed approach. Additionally, the proposed method compared to the previous DGT methods used for selective retention of $\mathrm{Cr}(\mathrm{VI})$ [11] avoids the use of DGT devices based on a time consuming and more expensive liquid binding layer.

\section{Conclusions}

For the first time, DE81 weak-anion-exchange discs, as used as the binding layer, were evaluated for the selective and quantitative retention of $\mathrm{Cr}(\mathrm{VI})$.

The proposed approach can be successfully applied in situ for selective $\mathrm{Cr}(\mathrm{VI})$ measurements in freshwater with a $\mathrm{pH}$ range from 4 to 9 and an ionic strength from 0.005 to $0.5 \mathrm{~mol} \mathrm{~L}^{-1} \mathrm{NaNO}_{3}$.

The redox speciation analysis of chromium using DGT was effectively performed by combining the selectivity of a DE81 membrane for $\mathrm{Cr}(\mathrm{VI})$ and the selectivity of Chelex-100 for the $\mathrm{Cr}$ (III) species.

\section{Acknowledgement}

The authors thank the Fundação de Amparo à Pesquisa do Estado de São Paulo (FAPESP, No. 2015/03397-4) and Conselho Nacional de Desenvolvimento Científico e Tecnológico (CNPq, Nos. 503070/2014-9 and 164326/2015-4) for their financial support.

\section{References}

[1] L. McNeill, J. Mclean, State of the Science of Hexavalent Chromium in Drinking Water, Water Research Foundation, Denver, CO, 2012.

[2] D. Barałkiewicz, B. Pikosz, M. Belter, M. Marcinkowska, Speciation analysis of chromium in drinking water samples by ion-pair reversed-phase HPLC-ICPMS: validation of the analytical method and evaluation of the uncertainty budget, Accredit. Qual. Assur. 18 (2013) 391-401, http://dx.doi.org/10.1007/ s00769-013-1002-y.

[3] K.R. Di Bona, S. Love, N.R. Rhodes, D. McAdory, S.H. Sinha, N. Kern, et al., Chromium is not an essential trace element for mammals: effects of a "low- chromium diet, J. Biol. Inorg. Chem. 16 (2011) 381-390, http://dx.doi.org/ 10.1007/s00775-010-0734-y.

[4] (Background document for development of (WHO) Guidelines for Drinkingwater Quality, Chromium in Drinking-water), 2003.

[5] 2008. CONAMA - National Environmental Council, Resolução n 397 de 2008, Brasilia, DF., 2008. 〈http://www.mma.gov.br/port/conama/legislacao/CON AMA_RES_CONS_2008_397.pdf $\rangle$ ((accessed) 02.22.16).

[6] W. Davison, H. Zhang, In-situ speciation measurements of trace components in natural-waters using thin-film gels, Nature 367 (1994) 546-548.

[7] H. Zhang, W. Davison, Performance-characteristics of diffusion gradients in thin-films for the in-situ measurement of trace-metals in aqueous-solution, Anal. Chem. 67 (1995) 3391-3400.

[8] H. Zhang, W. Davison, S. Miller, W. Tych, In-situ high-resolution measurements of fluxes of NI, CU, FE, and MN and concentrations of ZN and CD in porewaters by DGT, Geochim. Cosmochim. Acta 59 (1995) 4181-4192.

[9] D.M. Templeton, F. Ariese, R. Cornelis, L.G. Danielsson, H. Muntau, H.P. Van Leeuwen, et al., Guidelines for terms related to chemical speciation and fractionation of elements. Definitions, structural aspects, and methodological approaches (IUPAC Recommendations 2000), Pure Appl. Chem. 72 (2000) 1453-1470, http://dx.doi.org/10.1351/pac200072081453.

[10] H. Ernstberger, H. Zhang, W. Davison, Determination of chromium speciation in natural systems using DGT, Anal. Bioanal. Chem. 373 (2002) 873-879, http: //dx.doi.org/10.1007/s00216-002-1370-3.

[11] H. Chen, Y.Y. Zhang, K.L. Zhong, L.W. Guo, J.L. Gu, L. Bo, et al., Selective sampling and measurement of $\mathrm{Cr}(\mathrm{VI})$ in water with polyquaternary ammonium salt as a binding agent in diffusive gradients in thin-films technique, J. Hazard. Mater. 271 (2014) 160-165, http://dx.doi.org/10.1016/j.jhazmat.2014.02.022.

[12] Y. Pan, D. Guan, D. Zhao, J. Luo, H. Zhang, W. Davison, Novel Speciation Method Based on Diffusive Gradients in Thin-Films for in Situ Measurement of CR, 2015, doi: 10.1021/acs.est.5b03742.

[13] L. Guo, H. Chen, Y. Zhang, L. Bo, J. Li, Determination of chromium speciation in tap water using diffusive gradients in thin film technique, Chem. Lett. 43 (2014) 849-850, http://dx.doi.org/10.1246/cl.140100.

[14] A.W.W.A. American Public Health Association, ed., 3500-Cr B. Colorimetric Method, Stand. Methods Exam. Water Wastewater, 1999.

[15] A.M.C.M. Rolisola, C.A. Suárez, A.A. Menegário, D. Gastmans, C.H. Kiang, C. D. Colaço, et al., Speciation analysis of inorganic arsenic in river water by Amberlite IRA 910 resin immobilized in a polyacrylamide gel as a selective binding agent for $\mathrm{As}(\mathrm{V})$ in diffusive gradient thin film technique, Analyst 139 (2014).

[16] H. Zhang, W. Davison, Diffusional characteristics of hydrogels used in DGT and DET techniques, Anal. Chim. Acta 398 (1999) 329-340.

[17] C.D. Colaço, L. Nozomi, M. Yabuki, A. Lodovico, A. Antonio, C.D. Colaco, et al., Diffusion coefficients of metals in non-conventional materials (agarose and cellulose acetate) used in the diffusive gradients in thin films technique, Quim. Nova 35 (2012) 1360-1364.

[18] R.A. Griffin, J.J. Jurinak, Griffin - soil science formula força ionica, Soil Sci., 116, (1973) 26-30.

[19] W.J. Li, J.J. Zhao, C.S. Li, S. Kiser, R.J. Cornett, Speciation measurements of uranium in alkaline waters using diffusive gradients in thin films technique, Anal. Chim. Acta 575 (2006) 274-280, http://dx.doi.org/10.1016/j. aca.2006.05.092.

[20] B.L. Larner, A.J. Seen, Evaluation of paper-based diffusive gradients in thin film samplers for trace metal sampling, Anal. Chim. Acta 539 (2005) 349-355, http: //dx.doi.org/10.1016/j.aca.2005.03.007. 